\title{
Immune response characterization in HIV/HCV co- infected patients of medicine tropical foundation
}

\author{
Adriana Malheiro ${ }^{1,3^{*}}$, Liziara Silva Fraporti ${ }^{1,3}$, Flamir Victoria ${ }^{2}$, Kátia Luz Torres ${ }^{1}$, João Paulo Diniz Pimentel ${ }^{1}$, \\ Andrea Tarragô ${ }^{1}$, Laura Patricia Viana Maia ${ }^{1,3}$, Felicien Vásquez ${ }^{1}$, José Eduardo Levi ${ }^{4}$, Marilu Victoria ${ }^{2}$ \\ From $16^{\text {th }}$ International Symposium on HIV and Emerging Infectious Diseases \\ Marseille, France. 24-26 March 2010
}

\section{Background}

The epidemiology of co-infection of human immunodeficiency virus and hepatitis $\mathrm{C}$ virus $(\mathrm{HIV} / \mathrm{HCV})$ is around 30 to $60 \%$. Approximately one third of HIV infected shows $C$ hepatitis, with a high rate in hemophiliacs and drug users. Recent publications demonstrated that HIV positive patients co-infection with $\mathrm{HCV}$ have a co-factor to develop AIDS. The purpose of this study was evaluate the cellular and humoral immune response and cytokines in $\mathrm{HIV} / \mathrm{HCV}$ co-infected patients in Foundation of Tropical Medicine of Amazonas.

\section{Methods}

After consent term assignature, the population of $\mathrm{T}$ lymphocytes $\mathrm{CD} 4^{+}$and $\mathrm{CD} 8^{+}$was analyzed in the whole blood by flow cytometry and a blood sample was take to measure the serum concentration of inflammatory cytokines (interleucine - IL - 6, 8 and tumoral necrosis factor alpha-TNF- $\alpha$ ), cytokines of $\mathrm{T}_{\mathrm{H}} 1$ (IL-12, Interferon gamma-IFN- $\gamma$ ) cytokines $\mathrm{T}_{\mathrm{H}} 2$ (IL-4) and suppression cytokine (IL-10) using ELISA BD OptEIA ${ }^{\bullet}$ kit.

\section{Results}

As for $\mathrm{CD} 4^{+} \mathrm{T}$ cells $72.2 \%$ had $<500 \mathrm{cls} / \mathrm{mm} 3$ with a median of $271 \mathrm{cls} / \mathrm{mm} 3$, on the $\mathrm{T} \mathrm{CD} 8^{+} 88.9 \%$ had $\geq 215$ $\mathrm{cls} / \mathrm{mm} 3$ with a median of $794.5 \mathrm{cls} / \mathrm{mm} 3$. The ratio $\mathrm{CD} 4^{+} / \mathrm{CD}^{+}{ }^{+}$was $0.32 \mathrm{cls} / \mathrm{mm} 3$. When the dose cytokines IL-4, IL-6, IL-8, IL-10, IL-12 and IFN- $\gamma$ in the patients found that only the IL-6 $(\mathrm{p}=<0.001)$ showed statistical significance especially when correlated to the logarithm of the HCV viral load (0.031).

\footnotetext{
* Correspondence: elisadleon@yahoo.com.br

${ }^{1}$ Fundação de Hematologia e Hemoterapia do Amazonas, Manaus, Brazil
}

\section{Discussion}

The results found in this study, despite the low prevalence, have annual growth of co-infection due to improvement in the research of hepatitis $C$ in patients with HIV and the IL- 6 cytokine was important marked of inflammation in this studied population.

\section{Financial support}

FHEMOAM, FAPEAM.

\section{Author details}

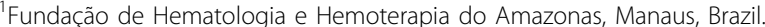
${ }^{2}$ Fundação de Medicina Tropical do Amazonas, Manaus, Brazil. ${ }^{3}$ Universidade Federal do Amazonas, Manaus, Brazil. ${ }^{4}$ Universidade Estadual de São Paulo, São Paulo, Brazil.

Published: 11 May 2010

\section{doi:10.1186/1742-4690-7-S1-P80}

Cite this article as: Malheiro et al.: Immune response characterization in HIV/HCV co-infected patients of medicine tropical foundation. Retrovirology 2010 7(Suppl 1):P80.

\section{Submit your next manuscript to BioMed Central and take full advantage of: \\ - Convenient online submission \\ - Thorough peer review \\ - No space constraints or color figure charges \\ - Immediate publication on acceptance \\ - Inclusion in PubMed, CAS, Scopus and Google Scholar \\ - Research which is freely available for redistribution

